\title{
CBC NEWS COVERAGE OF CANADA'S 2006 LIBERAL PARTY LEADERSHIP CANDIDATES*
}

Stephen J. Farnsworth

Department of Political Science and International Affairs

University of Mary Washington

1301 College Avenue

Fredericksburg, VA 22401

Phone: 540-654-1508

Fax: 540-654-1482

E-mail: sfarnswo@umw.edu

\author{
S. Robert Lichter \\ Professor of Communication, George Mason University \\ President, Center for Media and Public Affairs
}

and

Roland Schatz

CEO, Media Tenor International

* NOTE: Please direct all comments and correspondence to Farnsworth. Thank you.

\begin{abstract}
Content-coded CBC evening newscasts are used to examine reports on the eight candidates for Liberal Party Leader in the weeks before the party's 2006 convention. In a sharp contrast news reports on U.S. presidential nominations, "The National” provided coverage balanced between the horse race and more substantive matters, including policy discussions and a candidate's personality and leadership qualities. But like US nomination coverage, "The National” largely ignored trailing candidates, focusing nearly all of its attention on the likely and plausible nominees. In terms of tone, "The National” provided "compensatory coverage," where frontrunners were more treated more negatively than the candidates further back in the field.

NOTE: The authors thank Markus Rettich of Media Tenor International for his vital research assistance. Thanks also to the Canada/U.S. Fulbright Program, the McGill Institute for the Study of Canada, the Center for Media and Public Affairs and the University of Mary Washington for financial support. All errors and interpretations remain the authors' responsibility.
\end{abstract}


Throughout 2006, Canada’s Liberal Party worked its way through an identity crisis. From the victory of Stephen Harper's Conservatives in January through the selection of Stéphane Dion as the Liberal leader in December, party activists debated the once dominant party's future (Sears 2007). In the months leading up to the five day convention that started on November 28, Liberal activists found it difficult to coalesce around a single candidate, with four candidates enjoying double-digit support among the delegates (Laghi 2006). Dion's selection did not resolve the party's troubles. After the convention, some Liberals began expressing their doubts about the new leader, and polls showed the Liberals' post-convention bounce in the polls quickly flattened (MacDonald 2007; Thompson 2007; Ward 2007).

This study examines weekday campaign news coverage of the Liberal campaign on "The National," the flagship evening newscast of the CBC, from October 23 through December 1, the eve of Dion's selection as leader on December 2. These six weeks represent the period of greatest media and public interest in the contest. The content analysis, conducted by Media Tenor International, a non-partisan media research institute, examines dimensions of candidate "horse-race” standings as well as more substantive matters, and it compares the coverage the eight Liberal leadership candidates in terms of volume of coverage and tone of those news reports.

This study examines whether key findings relating to research on television news coverage of U.S. presidential nomination campaigns can be applied to the very different party nomination process in Canada's Liberal Party. Such a comparison can help develop a distinctly Canadian perspective to the growing literature on news coverage of party nominations. In the US, campaign news is marked mainly by horse-race coverage that focuses primarily on frontrunners and a tonal imbalance that treats front-runners more harshly than their main rivals (cf., Farnsworth and Lichter 2007a, 2007b; Patterson 1994; Robinson and Sheehan 1983).

\section{Canadian Leadership Contests and US Nomination News Coverage}

Unlike American party conventions, which in recent election cycles have functioned more like first-ballot coronations, Liberal Party conventions in Canada are sometimes unpredictable and often involve several rounds of balloting (Courtney 1995; 2003). Never was that more true than during the Liberals' 2006 contest, which involved four viable contenders in an eight-candidate field (Laghi 2006). Stéphane Dion, the eventual winner, entered the 2006 convention well behind the front-runner in number of pledged delegates, but emerged victorious in the multi-ballot wide-open competition for votes (Sears 2007). Convention delegates, the party's true believers, evaluate both past governmental performance and the electoral prospects of leadership candidates, creating environments in which dark horses can defeat frontrunners (Maioni 2007). In addition, internal policy disputes in a party can often trigger viable leadership challenges on substantive matters, which also can lead to convention upsets (Carty et al. 2000; Cross and Young 2002). The stakes for the party and for Canada are high: every single Liberal Party leader selected in conventions during the six decades before the 2006 contest became prime minister (Courtney 2003).

Recent research on party organizations in Canada suggest that parties are increasingly becoming fragmented, with regional bases of support rather than national ones that formerly held sway (Carty et al. 2000; Carty 2006; Cross and Young 2002). That trend can exacerbate a party’s identity crisis, a factor in the unusually volatile Canadian politics of recent decades (Carty et al. 2000; Carty 2006; Cross and Young 2002). 
Delegates to Liberal conventions are selected in local ridings by party members, and are pledged to a candidate only for the first ballot (Courtney 2003). Local factors play a key role in selection of delegates and party candidates, and national parties like the Liberals sometimes find it difficult to bring disparate regional elements together (Carty 2002, 2006; Thompson 2007). In the US, most convention delegates are selected in primaries, and while their loyalty also only extends to the first ballot, a second ballot has not been necessary to select a Democratic or Republican presidential nominee in decades (Ceaser and Busch 2001, 2005; Polsby and Wildavsky 2000).

Simultaneous delegate selection across Canada means that Liberal candidates enter the convention with a clear knowledge of their relative standing - a ranking that is relatively fixed during the weeks leading up to the party meeting. While candidates in both countries rely heavily on support from their home regions at the campaign's outset, Canadian leadership candidates are not able to use success in early nomination contests (like US caucuses and primaries) to create a "bandwagon" movement that can propel them to greater successes in the following days and weeks of the US competition (Patterson 1980). At most, leadership candidates in Canada can claim their performance in the early ballots represents momentum for additional gains in subsequent ballots, conducted only hours later.

There are also media differences of note. US television is dominated by three broadcast networks (ABC, CBS and NBC), all of which are owned by for-profit companies. CBC, in contrast, is a government-assisted broadcaster. But there are some similarities. CBC faces private sector competition for audience share, and the broadcaster is under pressure to maximize advertising revenue to finance its news and entertainment programming, as are the leading forprofit US broadcast networks (Fraser 2000).

While the party nomination process and the media environment differ in both nations, research has found considerable similarity in news coverage of governing issues in the US and Canada by CBC and the dominant US broadcast networks (cf., Farnsworth et al. 2007; Soderlund et al. 1994; Wittlebols 1992, 1996). In addition, past research has found great similarities in reporter norms and media outlet approaches employed on both sides of the border (Hallin and Mancini 2004). While using US research models for a study of CBC nomination coverage is far from ideal, the relative absence of comparable content analysis studies of Canadian nomination news leaves no good alternative.

Studies of television news coverage of US presidential nominations and elections found several key problems, including (1) a heavy emphasis on "horse-race" coverage of poll standings at the expense of discussion of more substantive matters; (2) coverage that is not fairly allocated among the candidates and (3) a tone of coverage that is unfair, with some candidates treated more negatively than others (Farnsworth and Lichter 2007a, 2007b; Iyengar 1991; Kerbel 1998; Patterson 1994; Robinson and Sheehan 1983).

The highly fluid nomination process in the US may encourage greater focus on the daily poll results at the expense of more substantive reporting. In the 2004 Democratic nomination competition, for example, former Vermont Governor Howard Dean led in 16 of the 22 New Hampshire tracking polls conducted by American Research Group in the weeks before that state's crucial first-in-the-nation primary, often by double digit margins (Farnsworth and Lichter 2006). U.S. Sen. John Kerry (D-MA), the eventual nominee, was ahead only in the final six tracking polls, all conducted at least in part after his come-from-behind Iowa Caucus victory. 
Polls of New Hampshire voters in previous primary years likewise show rapid voter movement from candidate to candidate (Farnsworth and Lichter 1999, 2002, 2003). The 2006 Liberal Party leadership competition, in contrast, was volatile primarily during the convention itself, and only after the pledged delegates fulfilled their first ballot obligations (Laghi 2006; Maioni 2007; Sears 2007).

The second issue raised in studies of US nomination news, the inequality in the amount of coverage devoted to participants, is crucial for leadership candidates on both sides of the border. Since nearly all leadership hopefuls are largely unknown nationally, one of the key challenges candidates face is to build name recognition outside their home states and provinces. Candidates who reporters believe are doing well receive more attention, which can increase their chances of becoming a more serious contender, and ultimately prevailing in the nomination process (Mayer 2004). The news media are key vehicles for a candidate to become better known outside one's own home region in both countries. Indeed, the importance of media coverage may be even greater for Canadian candidates, since US candidates can use more money and have much more time to become better known (Burden 2005; Farnsworth and Lichter 2007b).

Past studies of news coverage of US presidential nominations suggest that a form of journalistic triage takes place well before the votes are cast (Robinson and Sheehan 1983). For purposes of allocating scarce media resources, candidates are characterized by reporters as "hopeless," "plausible,” and "likely." The "likely” nominees, also known as front-runners, get a lot of coverage by virtue of their status. The "plausible" candidates, the middle category, get some coverage, but not as much as a front-runner. The "hopeless" candidates receive little coverage unless the campaigns show some signs of life, which probably won't happen without more media coverage (Robinson and Sheehan 1983). Although the typology was developed in an analysis of the 1980 nomination contests, the pattern holds in the 2004 Democratic nomination competition and in other recent campaigns (Farnsworth and Lichter 2007b).

Research on US presidential nominations also finds tonal imbalances in the treatment of candidates. Front-runners sometimes suffer more intense media scrutiny, while candidates behind in the polls sometimes obtain "compensatory coverage," reporting that is more positive in tone than that relating to the front-runner (Robinson and Sheehan 1983). This pattern, observed in 1980, was also found in the 2004 Democratic nomination contest, when U.S. Sen. John Edwards (D-NC), who became the main rival to Kerry after Dean stumbled, received more positive coverage than did Kerry. Dean, the front-runner in late 2003, received the most negative coverage in 2004, largely because of extensive coverage of his infamous "scream," after the Iowa Caucus (Burden 2005; Farnsworth and Lichter 2007a, 2007b). The incident, which to some cast doubts on Dean's temperament for high office, demonstrated that extraordinary candidate behavior can create exceptions to the candidate triage model, though in a way that hurts the candidate's media image.

\section{Hypotheses}

H1: CBC television reporters focus more on horse-race news reports of the campaign than policy, character and other more substantive matters, and the media devotion to horse-race matters increases as the date of candidate selection draws closer.

H2: The better a candidate's anticipated performance in the first ballot of the 2006 Liberal leadership campaign the more news coverage focused on that candidate.

H3: Middle-tier candidates (also known as the "plausible” nominees) and lower-tier 
candidates (also known as "hopeless" nominees) receive news coverage that is more positive in tone than news reports focused on the front runner.

\section{Methods and Measures}

This study examines how one of Canada's leading news sources - "The National” on CBC - reported on the 2006 Liberal leadership competition. CBC's flagship evening newscast is routinely examined by scholars who study Canadian news coverage (cf., Farnsworth et al. 2007; Miljan and Cooper 2005; Soderlund et al. 1994; Wittlebols 1992, 1996). The study examines every weekday newscast starting on October 23 and ending with the newscast on December 1, the evening before Dion's selection. Two days of “The National” were unavailable for technical reasons (Nov. 6 and Nov. 10). There is no reason to suspect those two missing days were atypical in news content or influence, given that those two missing news programs aired several weeks before the leadership convention.

(Table 1 about here)

A total of 1179 statements on or by the eight leadership candidates were examined. Those statements came from 39 stories that focused on the leadership campaign from a total of 764 stories that aired on "The National” during the study period. As shown in Table 1, coverage of the Liberal leadership campaign was the subject of more than 5 percent of the program's news stories only in the final two weeks before Dion's selection. For the survey period as a whole, only 5.1 percent of the stories related to the leadership campaign. Roughly ninety percent of the statements on or by the candidates - 1065 out of 1179 - were found in the newscasts that aired on November 20 or later.

The content coding process used here involves analyzing and tabulating individual statements during the CBC evening newscasts that contain explicitly positive or negative judgments of the candidates with respect to their political prospects (the "horse-race") or to more substantial matters, which include character, policy stances and the candidate's professional competence. Native speakers of English were hired by Media Tenor International, a nonpartisan research firm, to code these campaign news reports after undergoing intensive content analysis training conducted by Media Tenor staff. Intercoder reliability exceeds .77 for all variables used here.

With respect to the horse race, a candidate reported to be "gaining ground" has received a positive horse-race evaluation, while one said to be "slipping” has received a negative horse-race evaluation. Under the coding system used here, some campaign-related measures are considered substantive evaluations if those issues are linked to character issues rather than horse-race standings. Examples of campaign issues that may relate to character and thus are classified as substantive evaluations here include whether a candidate is said to be making misleading or deceptive campaign statements, is too close to special interests or is conducting a divisive campaign. All of these would be coded as negative substantial evaluations. (Further discussion of the methodology used can be found on the Media Tenor website (www.mediatenor.com).

A Strategic Council survey of the Liberal party's delegates on the eve of the national convention demonstrated how divided the party was in December 2006. Harvard academic turned politician Michael Ignatieff had the first ballot support of 31 percent of the delegates, a double-digit lead over the other seven candidates. But three others were bunched just below 20 percent support, making them viable contenders: former Ontario Premier Bob Rae (formerly of the New Democratic Party) had the support of 19 percent of the delegates, former Université de 
Montréal professor and former Liberal Environment Minister Stéphane Dion had the support of 18 percent, and Gerald Kennedy, a favorite of many of the younger delegates, was backed by 17 percent. The four other candidates trailed far behind: five percent of the delegates backed former Montreal Canadiens goalie Ken Dryden, three percent each backed Scott Brison and Joe Volpe, and Martha Hall Findlay had the support of one percent of the delegates. Another three percent of the delegates said they were undecided (Laghi 2006).

\section{Results}

Table 2 illustrates the structure of candidate and campaign coverage as it changed week by week. Overall, horse-race aspects of the campaign accounted for 45.9 percent of the news coverage, the single biggest category. The horse-race coverage was particularly intense - more than half of all coverage - during the final week of news analysis, which included the first few days of the convention itself. The substance/policy category, which amounted for just under onequarter of news coverage of the leadership campaign, included discussion of policy issues. More than half the coverage during the weeks of October 23 and October 30 focused on policy matters. The share of this substantive coverage fell to less than one-quarter of the coverage as the horserace coverage increased as the convention grew closer. Another substantive category leadership, which dealt with political experience and capability - comprised 9.4 percent of the coverage. Discussion of personality issues, also more a matter of substance than of the horserace, represented 8.8 percent of the coverage.

(Table 2 about here)

By US network television standards, the Canadian coverage was highly substantive, far less focused on the sports of politics than are nomination news reports south of the border. Although one should be wary of direct comparisons given the different nomination systems in each country, the cross-national differences are large. In the 2004 US presidential nomination campaigns, which involved only Democrats (President Bush was unopposed for the Republican nomination), 77 percent of the television coverage focused on the horse-race, as compared to 78 percent horse-race coverage in 2000, when both the Democrats and the Republicans faced competitive nomination challenges (Farnsworth and Lichter 2007a).

(Table 3 about here)

The "media triage" model of coverage nomination campaigns in the US appears to be an effective way to understand the 2006 Liberal campaign coverage in "The National” as well. Table 3 provides a study of both amount of campaign coverage and the tone of that coverage, broken down for each of the eight candidates. In the top half of Table 3, which examines amount and tone of all coverage, one sees that the leading candidate going into the convention - Ignatieff - received considerably more attention than his three strongest rivals, roughly 50 percent more coverage than each of them. But the plausible candidates - those ranked second to fourth in preconvention polls - received far more coverage than the bottom four candidates. Dion, Kennedy and Rae all received more than twice as much attention on the CBC than those polling in the single digits: Brison, Dryden, Findlay and Volpe.

Turning now to tone, one sees that the front-runner Ignatieff was treated most harshly on the CBC, with 28.1 percent negative coverage. Joe Volpe, a highly unlikely candidate, finished a very close second in the competition for negative press, in part because of a campaign finance scandal and an admonishment from the party for campaign irregularities shortly before the convention (Clark 2006). Like Howard Dean in 2004, unusual behavior on a candidate's part can 
create an exception to the general pattern of "compensatory coverage” normally enjoyed by the rivals to the front-runner.

Overall, the "compensatory coverage" model offers an effective explanation for coverage patterns for seven of the eight contestants. Other than Volpe, all the rest of Ignatieff's rivals received less negative coverage than the front-runner, often by a wide margin. Dion, the eventual winner, received coverage that was only 7 percent negative in tone, and Rae, who finished third in the convention, received coverage that was only 13.3 percent negative in tone. Kennedy, the other member of the Liberal Party's top four candidates, received coverage that was negative only 11.5 percent of the time. All three plausible leaders faced less than half the percentage of negative statements that Ignatieff received on "The National."

In addition to Volpe, only one other back-of-the-pack candidate received significant amounts of negative coverage. Many Liberals faulted Scott Brison for having been a Progressive Conservative - he had even once run for the leadership of that party - before he became a Liberal leadership candidate (Chase and Galloway 2006). But Brison's coverage was negative only 17 percent of the time, more negative than Dion or Rae or Kennedy but far less than the negativity directed at Ignatieff and Volpe.

The most positive coverage was enjoyed by Dion, followed closely by Kennedy, Findlay and Rae. All received positive assessments at least 20 percent of the time on "The National." The television reports had the smallest amount of positive things to say about the two most controversial candidates, Volpe and Brison (More than half of the coverage for all eight leadership candidates was mixed, or neutral, in tone).

The bottom half of Table 3 examines the news coverage for the subset of evaluations that do not relate to the horserace. The results here show the same patterns found in the overall assessments of amount of coverage: the front-runner received the most coverage, followed by the leading rivals, with only a small portion of the news focusing on the also-rans.

In terms of tone, Ignatieff was once again treated the most negatively, and the gap between Igantieff and Volpe widened considerably once the horse-race measures were excluded. In this subset of evaluations, the "compensatory coverage" patterns were even stronger, with larger gaps between the negative coverage Ignatieff received and that directed as his three closest rivals. The CBC news reports contained nothing about Volpe or Brison that was positive, once horse-race matters were excluded.

\section{Conclusion}

The fundamental finding of this study of news coverage of the 2006 Liberal leadership campaign was the extent to which the norms found in US nomination news coverage also exist north of the border. In terms of the relative amount of coverage the front-runner and his main rivals received, the Liberal competition was covered much the same way that US broadcast networks cover US nomination politics. The front-runner received the most attention, and the lower a candidate's standing, the less attention that campaign received. This cross-border similarity is a particularly striking finding when one considers the great differences in the nomination systems - a multi-ballot convention where delegates select the Liberal leadership candidate on the one hand, and a chaotic series of caucuses and conventions where the party faithful decide the Democratic and Republican nominees on the other. Cross-border differences, including culture, political identification and policy preferences (cf., Adams 2003), also might have led to more distinct campaign news coverage patterns in Canada. 
Similarities with US nomination news were also seen in "compensatory coverage," the tendency to treat front-runners more harshly than the plausible alternatives. While there were substantial differences in their personalities, the highly positive coverage that focused on John Edwards, the main rival to Kerry in 2004, resembled the highly favorable coverage Dion, Rae and Kennedy received as they lagged behind Ignatieff going into the 2006 convention.

The one major difference detected between nomination news in the two nations was in the relative attention paid to the horse-race. When one compares coverage of the 2006 Liberal leadership campaign to the 2000 and 2004 Democratic nomination struggles and the 2000 Republican nomination campaign, the Canadian example far outpaces US news performance in terms of substantive reporting. This is an important matter. Campaigns that are reported primarily as sporting events shortchange citizens who are interested in what the candidates would do if they were elected. Indeed, coverage of the sports of politics encourages citizens and political elites to discount issues when evaluating candidates (Patterson 1980, 1994).

One should not overstate the case, though. In Canada, the horse-race aspects of the campaign intensified as the 2006 Liberal Party convention drew closer and grew to dominate the news coverage in the days leading up to Dion's selection. In addition, one should note that horserace coverage may matter more in a process dominated by primary voters rather than by convention delegates. Canada's relative advantage in substantive coverage here, in other words, may be as much the result of a differing nomination system as any distinct media conceptions of news at the CBC.

The absence of published content analysis work on news of previous Liberal leadership campaigns makes it impossible to conclude that the $\mathrm{CBC}$ offers more substantive nomination campaign news generally. This lone study of one leadership contest does not allow researchers to detect a long-term pattern. In fact, the 2006 Liberal contest may have been an unusually substantive debate because both Dion and Igantieff, who finished first and second (and became party leader and deputy leader), were political scientists before becoming leadership candidates. In temperament, both are more policy wonks than populists, after all. The issue-focused discourse of 2006 may be less pronounced than in other Liberal leadership campaigns, particularly ones where career politicians were not so overshadowed by academics.

Although this paper looks solely at the Liberals' leadership competition of 2006, other researchers may wish to examine whether the coverage patterns identified in this paper are also found for news coverage of leadership contests in other political parties in Canada and during other election cycles. This is an interesting avenue of inquiry given the structural differences in nomination procedures in other Canadian parliamentary parties.

It may be that the difference in nomination news coverage between 2006 in Canada and 2004 in the US may be explained by a stronger CBC commitment to provide more serious news coverage. This study was too limited in scope to reach such an expansive conclusion, but studies of news coverage of other nomination campaigns, and other policy topics, by future researchers may help support such a claim. 
Table 1

Intensity of candidate coverage in "The National"

Week

10/23-10/27/2006

$10 / 30-11 / 3 / 2006$

$11 / 7-11 / 9 / 2006^{\star \star \star}$

$11 / 13-11 / 17 / 2006$

$11 / 20-11 / 24 / 2006$

$11 / 27-12 / 1 / 2006$

total (10/23-12/1/2006) share (\%) of candidate stories*

1.5

1.4

2.4

0.0

10.1

14.6

5.1 number of statements ${ }^{* *}$

44

28

42

0

380

685

1179 total number of news stories

130

148

85

133

138

130

764

Source: Media Tenor International $10 / 23-12 / 1 / 2006^{* * * *}$

Statements are defined as a combination of the subject (the politician), the aspect, the tone (evaluation) and the source. A change of the subject, aspect, evaluation or source has been coded as a new statement.

*: news stories which contain at least one statement on or by at least one of the eight candidates

**: total number of statements on or by the eight candidates

$\star \star *:$ 11/6 and $11 / 10$ editions missing for technical reasons 
Table 2

\section{Topic structure of candidate coverage in "The National"}

(As a percentage of all statements on or by the candidates)

\begin{tabular}{|c|c|c|c|c|c|c|}
\hline Week & $\begin{array}{l}\text { Policy } \\
\text { issues }\end{array}$ & leadership* & $\begin{array}{l}\text { horse } \\
\text { race }\end{array}$ & $\begin{array}{r}\text { personality } \\
\text { issues }\end{array}$ & $\begin{array}{l}\text { other } \\
\text { topics }\end{array}$ & $\begin{array}{r}\text { total number } \\
\text { of } \\
\text { statements }\end{array}$ \\
\hline $10 / 23-10 / 27 / 2006$ & 59.1 & 2.3 & 36.4 & 2.3 & 0.0 & 44 \\
\hline $10 / 30-11 / 3 / 2006$ & 67.9 & 0.0 & 17.9 & 0.0 & 14.3 & 28 \\
\hline $11 / 7-11 / 9 / 2006^{\star \star \star}$ & 38.1 & 7.1 & 52.4 & 0.0 & 2.4 & 42 \\
\hline $11 / 13-11 / 17 / 2006$ & 0.0 & 0.0 & 0.0 & 0.0 & 0.0 & 0 \\
\hline $11 / 20-11 / 24 / 2006$ & 18.9 & 8.9 & 38.7 & 17.6 & 15.8 & 380 \\
\hline $11 / 27-12 / 1 / 2006$ & 23.2 & 10.7 & 51.2 & 5.3 & 9.6 & 685 \\
\hline total $(10 / 23-12 / 1 / 2006)$ & 24.8 & 9.4 & 45.9 & 8.8 & 11.1 & 1179 \\
\hline
\end{tabular}

Note: Percentages may not add up to 100 percent because of rounding.

Source: Media Tenor International

$10 / 23-12 / 1 / 2006^{\star * *}$

*: political traits, experience and capability for the job

$\star *$ : nomination, campaigning, polls and forecasts

$\star \star \star$ : $11 / 6$ and $11 / 10$ editions missing for technical reasons 
Table 3

Tone of coverage for each candidate

$\begin{array}{lrrrr}\text { all topics (10/23 - 12/1/2006) } & & & \text { no } \\ & & & \begin{array}{r}\text { clear } \\ \text { rating }\end{array} & \begin{array}{r}\text { total number } \\ \text { of }\end{array} \\ \text { Candidate } & & & (\%) & \text { statements } \\ \text { Scott Brison } & \text { negative (\%) } & \text { positive(\%) } & 76.6 & 64 \\ \text { Stéphane Dion } & 17.2 & 28.2 & 64.8 & 213 \\ \text { Ken Dryden } & 7.0 & 11.6 & 76.7 & 86 \\ \text { Martha Hall Findlay } & 11.6 & 24.3 & 62.9 & 70 \\ \text { Michael Ignatieff } & 12.9 & 15.9 & 55.9 & 320 \\ \text { Gerard Kennedy } & 28.1 & 26.7 & 61.8 & 165 \\ \text { Bob Rae } & 11.5 & 23.2 & 63.5 & 211 \\ \text { Joe Volpe } & 13.3 & 6.0 & 66.0 & 50\end{array}$

"horse race" coverage excluded (10/23 - 12/1/2006)

$\begin{array}{lrrrr} & & & \begin{array}{r}\text { no } \\ \text { clear }\end{array} & \begin{array}{r}\text { total number } \\ \text { rating }\end{array} \\ \text { Candidate } & & \text { of } & \begin{array}{r}\text { negative (\%) } \\ \text { scott Brison }\end{array} \\ \text { Stéphane Dion } & 17.9 & 0.0 & 82.1 & 28 \\ \text { Ken Dryden } & 4.5 & 29.1 & 66.4 & 110 \\ \text { Martha Hall Findlay } & 4.7 & 2.3 & 93.0 & 43 \\ \text { Michael Ignatieff } & 7.5 & 22.5 & 70.0 & 40 \\ \text { Gerard Kennedy } & 25.1 & 16.8 & 58.1 & 167 \\ \text { Bob Rae } & 8.9 & 30.7 & 60.4 & 101 \\ \text { Joe Volpe } & 12.0 & 20.8 & 67.2 & 125 \\ & 20.8 & 0.0 & 79.2 & 24\end{array}$

Source: Media Tenor International

$10 / 23-12 / 1 / 2006$ *

*11/6 and 11/10 editions missing for technical reasons

Basis: a total of 1,179 statements on or by eight Liberal party candidates

Note: Percentages may not add up to 100 percent because of rounding. 


\section{REFERENCES}

Adams, Michael. 2003. Fire and Ice: the United States, Canada and the Myth of Converging Values. Toronto: Penguin Canada.

Burden, Barry. 2005. “The Nominations: Technology, Money and Transferable Momentum.” In The Elections of 2004, Michael Nelson, ed. Washington: CQ Press.

Carty, R. Kenneth. 2002. "The Politics of Tecumseh Corners: Canadian Political Parties as Franchise Organizations.” Canadian Journal of Political Science 35(4): 723-45. 2006. "Political Turbulence in a Dominant Party System.” PS: Political Science \& Politics 39(4): 825-7.

Clark, Campbell. 2006. "Volpe's prospects fading.” Globe and Mail (Toronto). December 4: A13.

Carty, R. Kenneth, William Cross, and Lisa Young. 2000. Rebuilding Canadian Party Politics. Vancouver: UBC Press.

Ceaser, James and Andrew Busch. 2001. The Perfect Tie: The True Story of the 2000 Presidential Election. Lanham, Md.: Rowman and Littlefield.

. 2005. Red over Blue: The 2004 Elections and American Politics. Lanham, Md.: Rowman \& Littlefield.

Chase, Steven, and Gloria Galloway. 2006. “Brison's choices: Will they haunt him?” Globe and Mail (Toronto). December 4: A12.

Courtney, John C. 1995. Do Conventions Matter? Choosing National Party Leaders in Canada. Montreal and Kingston: McGill-Queen’s University Press.

November).

2003. “Picking a leader.” The Beaver: Exploring Canada's History 83(5): 6-7. (October-

Cross, William, and Lisa Young. 2002. "Policy Attitudes of Party Members in Canada: Evidence of Ideological Politics.” Canadian Journal of Political Science 35(4): 859-880.

Farnsworth, Stephen J., and S. Robert Lichter. 2006. “The 2004 New Hampshire Democratic Primary and Network News.” Harvard International Journal of Press/Politics 11(1): 5363.

. 2007a. The Nightly News Nightmare: Network Television's Coverage of U.S. Presidential

Elections, 1988-2004. Lanham, Md.: Rowman \& Littlefield. Second Edition. 
2007b. "How Television Covers the Presidential Nomination Process.” In The Making of the Presidential Candidates, 2008, William G. Mayer, ed. Lanham, Md.: Rowman \& Littlefield.

Farnsworth, Stephen J., Stuart Soroka, and Lori Young. 2007. "Canadian TV news on Bush and Iraq: No more hostile than top US network.” Policy Options July/August 88-94.

Fraser, Matthew. 2000. “The CBC’s Choice: Constellations or Core Competencies?” Policy Options. September 43-49.

Hallin, Daniel C., and Paolo Mancini. 2004. Comparing Media Systems: Three Models of Media and Politics. New York: Cambridge University Press.

Iyengar, Shanto. 1991. Is Anyone Responsible? How Television Frames Political Issues. Chicago: University of Chicago Press.

Kerbel, Matthew R. 1998. Edited for Television: CNN, ABC and American Presidential Elections. Boulder, CO: Westview.

Laghi, Brian. 2006. “Dion picks up steam in home stretch.” Globe and Mail (Toronto). November 28: A1.

Maioni, Antonia. 2007. "What I Saw at the Liberal Party.” Policy Options. February: 46-49.

MacDonald, L. Ian. 2007. "Liberal bad blood: Lapierre's resignation shows the tension in party ranks.” The Gazette (Montreal). January 15: A19.

Mayer, William G. 2004. "The Basic Dynamics of the Contemporary Nomination Process: An Expanded View.” In The Making of the Presidential Candidates, 2004, ed. William G. Mayer. Lanham, MD: Rowman \& Littlefield.

Miljan, Lydia, and Barry Cooper 2005. “The Canadian 'Garrison Mentality’ and AntiAmericanism at the CBC.” Studies in Defense and Foreign Policy. Vancouver, BC: Fraser Institute.

Patterson, Thomas E. 1980. The Mass Media Election: How Americans Choose Their President. New York: Praeger. 1994. Out of Order. New York: Vintage.

Polsby, Nelson, and Aaron Wildavsky. 2000. Presidential Elections: Strategies and Structures of American Politics. $10^{\text {th }}$ ed, New York: Chatham House/Seven Bridges.

Robinson, Michael J., and Margaret A. Sheehan. 1983. Over the Wire and On TV: CBS and UPI 
in Campaign '80. New York: Russell Sage Foundation.

Sears, Robin V. 2007. “Stumbling Out of a Hall of Mirrors.” Policy Options. February: 17-28.

Soderlund, Walter, Ronald H. Wagenberg, and Ian C. Pemberton. 1994. "Cheerleader or Critic? Television News Coverage in Canada and the United States of the US Invasion of Panama." Canadian Journal of Political Science 27(3): 581-604.

Thompson, Elizabeth. 2007. “Liberals close discussions to media.” The Gazette (Montreal). June 16: A15

Ward, John. 2007. "Tories, Liberals in political dead heat, new poll suggests.” The Gazette (Montreal). January 4: A9.

Wittlebols, James H. 1992. "Media and the Institutional Perspective: U.S. and Canadian Coverage of Terrorism.” Political Communication 9:267-278.

. 1996. "News from the Noninstitutional World: U.S. and Canadian Television News Coverage of Social Protest.” Political Communication 13:345-361. 